\title{
Mathematical Models for Leaf Area Estimates of Guava
}

\author{
Edney L. da Vitória ${ }^{1}$, Ismael L. de J. Freitas ${ }^{1}$, Tamara Locatelli ${ }^{2}$, Elcio das G. Lacerda ${ }^{3}$, Juliana M. Valle ${ }^{1}$, \\ Raphaela C. Pereira ${ }^{1}$, Paloma F. P. de Almeida ${ }^{1}$, Rafael Z. da Vitória ${ }^{1}$, \\ Carla da P. Simon ${ }^{4} \&$ Adriano A. Fernandes ${ }^{1}$ \\ ${ }^{1}$ Department of Agrarian and Biological Sciences, Federal University of Espirito Santo, São Mateus, ES, Brazil \\ ${ }^{2}$ Postgraduate in Plant Production, State University of North Fluminense, Campos, RJ, Brazil \\ ${ }^{3}$ Department of Agronomy, Federal Institute of Espírito Santo, Santa Teresa, ES, Brazil \\ ${ }^{4}$ Postgraduate in Nuclear Energy in Agriculture and the Environment, University of São Paulo, SP, Brazil \\ Correspondence: Edney L. da Vitória, Federal University of Espirito Santo, São Mateus, ES, Brazil. E-mail: \\ edney.vitoria@ufes.br
}

Received: August 13, 2018

doi:10.5539/jas.v10n12p272
Accepted: September 16, $2018 \quad$ Online Published: November 15, 2018

URL: https://doi.org/10.5539/jas.v10n12p272

\begin{abstract}
The aim of this work was to compare methods of determining the leaf area of guava (leaf discs and scanned images) and to model leaf area as a function of linear dimensions. Four areas of guava 'Paluma' were selected $(12,15,20$ and 24 months of age) for the experiment in the municipality of Pedro Canário, ES, Brazil. We randomly collected samples from 15 plants in each area. Ten leaves were chosen among the lower, middle and upper thirds of each plant to ensure that leaves of all sizes were collected, for a total of 600 leaves. Subsequently, we determined the leaf area by the methods of digital imaging and leaf discs. Linear regression analysis and correlation analysis were used to compare the methods. Linear, quadratic and power models of leaf area, as a function of the length or width and/or the product of length and width were adjusted. The methods of leaf discs and scanned images are discordant. The method of digitised images was a better fit to the width of the leaf, while the method of leaf discs was a better fit for length.
\end{abstract}

Keywords: scanned images, leaf discs, modelling, non-destructive method

\section{Introduction}

Guava, in Brazil, is grown in three different production systems to cater to different markets: cultivation for table guava, for industry and for mixed uses. The latter system aims to serve both markets simultaneously, which is an advantage for producers, as the best quality fruits are intended for in nature fruit markets at premium prices, and the remainder are intended for processing into different products according to the type of fruit (Ramos et al., 2010; Pereira \& Kavati, 2011).

The leaf area of fruit trees is an important characteristic because it is directly related to cultural processes and management systems, as it affects photosynthetic capacity, light interception, interference with ground cover, competition with other plants, water loss, and determination of pesticide spray coverage, among others (Morgado et al., 2013; Bosco et al., 2012).

The area of a leaf can be obtained by indirect, non-destructive methods, such as mathematical models or equations that estimate, with reasonable accuracy, leaf area as a function of linear dimensions (such as length, width and/or the product of both). The ease and speed of execution and low cost are important (independent of modern, expensive equipment) because these methods do not cause destruction of the plant, and this allows measurements to be made several times on the same individual (Silva et al., 2002; Araújo et al., 2005; Maldaner et al., 2009; Lima et al., 2012).

Recent research was conducted to develop equations that relate the length, width or the product of both to the leaf area of some fruit trees, such as passion fruit (Morgado et al., 2013), mango (Lima et al., 2012), apple (Bosco et al., 2012), acerola (Lucena et al., 2011) and vines (Borghezan et al., 2010), with a high degree of accuracy. However, there are no reports on the estimation of leaf area in guava, and for this fruit, leaf area could be an important tool for assessing growth, productivity and phytosanitary treatments. 
The aim of this study was to establish mathematical models based on the evaluation of linear measurements made on leaves of guava 'Paluma' to estimate the leaf area.

\section{Methodology}

The study was conducted in the district of Crystal North, Municipality of Pedro Canary, northern Espírito Santo region $\left(18^{\circ} 17^{\prime} 33^{\prime \prime} \mathrm{S}, 39^{\circ} 57^{\prime} 26^{\prime \prime} \mathrm{W}\right.$, elevation $\left.65 \mathrm{~m}\right)$. The region is classified by Köppen as a tropical rain forest and climate (Am), and the soil is classified as dystrophic Ultisol.

In September 2017, we selected four areas of guava 'Paluma', 12, 15, 20 and 24 months old, spaced $6.5 \times 4.0 \mathrm{~m}$. The orchards were formed by transplanting trees, and certification was formed through cutting. Until the establishment of the experiment, these plants had not yet been subjected to pruning.

We randomly selected 15 plants in each of the areas previously marked for study. Ten leaves were chosen among the lower, middle and upper thirds of the plant to ensure that leaf material of all lengths and widths was collected, totalling 600 leaves.

For each leaf, linear measurements of length and width were made. The length measurement was taken along the central rib, from the apex of the leaf to the intersection of the blade and the stem. For the width, the greatest width perpendicular to the alignment of the central rib was used. Both measurements were in centimetres using a graduated scale to the nearest $0.1 \mathrm{~cm}$.

After determining the linear measurements, scanned images of each leaf were obtained using a flatbed scanner (HP brand, model Scanjet Enterprise 7500 Flow with a scan resolution of $600 \mathrm{dpi}$ ), and the images were processed using ImageJ software, version 3.0 (RASBAND, 2012). This software used an algorithm that integrates the digitised image using the technique of measurement and classification of objects on the digital image surface. Subsequently, with the aid of an auger (diameter of $35 \mathrm{~mm}$ ), the maximum possible number of discs of the lamina, including the ribs, were made.

Samples of leaf discs and the remainder of each leaf were separately packed into paper bags and dried in an oven with forced aeration and a temperature of $65^{\circ} \mathrm{C}$ to constant weight. The dry mass of the two portions was determined using an electronic balance with a $1 \mathrm{mg}$ resolution and a $5 \mathrm{mg}$ accuracy. The total area of each leaf in $\mathrm{cm}^{2}$ was calculated using the Equation 1:

$$
A F=\frac{M S T-A T D}{M S D}
$$

Where, MST is the total dry mass of the leaves, ATD is the total area of the discs and MSD is the dry mass of the discs.

The lengths, widths, products of length and width and leaf areas were determined digitally through the leaf disc images. Measures of central tendency, variability, skewness and kurtosis were calculated and checked for normality using the Kolmogorov-Smirnov test $(\mathrm{p}<0.05)$.

The evaluation of the agreement between the methods of determining leaf area, scanned images and weighing leaf discs, was performed with the adjustment of a simple linear regression, where the leaf area determined by digitalised images was considered the dependent variable and the leaf area using leaf discs was the independent variable.

Prior to fitting the models, data for length, width and leaf area were subjected to Bartlett, Kolmogorov-Smirnov and Durbin-Watson tests to verify the homogeneity of variance, normal distribution of residuals and data independence, respectively. If the data set displayed the characteristics of homogeneity of variance, normal distribution and independence, these data would be used without any processing (Bosco et al., 2012).

For each model tested, the significance of the coefficients was determined using the Student $t$ test at 5\% significance. Then, the coefficients of linear correlation (r) and determination $\left(\mathrm{R}^{2}\right)$ between the values of the estimated and observed area were calculated. The significance of " $r$ " was evaluated by the Student $t$-test at $5 \%$ significance. For each model, the mean absolute error (MAE), the root mean square error (RMSE) and the Willmott index (d) (Willmott et al., 1985) were calculated using the Equations 2, 3 and 4:

$$
\begin{gathered}
E A M=\frac{\sum_{i=1}^{n}\left|\hat{Y}_{i}-Y_{i}\right|}{n} \\
R Q M E=\sqrt{\frac{\sum_{i=1}^{n}\left(\hat{Y}_{i}-Y_{i}\right)^{2}}{n}}
\end{gathered}
$$




$$
d=\left[\frac{\sum_{i=1}^{n}(\hat{Y} i-Y i)^{2}}{\sum_{i=1}^{n}(\hat{Y} i-\bar{Y}|+| Y i-\bar{Y} \mid)^{2}}\right]
$$

Where, yi are the estimated values of leaf area, Yi are the observed values of leaf area, $\bar{Y}$ is the average of the observed values and $n$ is the number of leaves $(n=600)$. After obtaining these values, we determined the Camargo and Sentelhas (1997) index (CS) $(\mathrm{CS} \times \mathrm{d}=\mathrm{r})$.

The criteria used for selection of the best models that estimate the leaf area as a function of the length or width and/or the product of both were the following: the linear coefficient was (a) non-zero and (b) no different from the slope; coefficients of linear correlation (r) and determination $\left(\mathrm{R}^{2}\right)$ were close to one; the mean absolute error (MAE) and root mean square error (RMSE) were close to zero; and the indices "d" and CS were close to one. The best models were arranged in rank order, with the best fit for each model chosen to perform the validation and performance tests. The validation and the performance tests of the selected models were performed with data from lengths, widths and leaf areas obtained from 500 leaves.

The generation and evaluation of the models were performed in R (2013) software.

\section{Results and Discussion}

The measures of central tendency, variability, skewness and kurtosis, in relation to the length (L), width (W), the product of length and width $(\mathrm{L} \times \mathrm{W})$, the leaf area determined by digital images (ID) and the leaf area determined by leaf discs (DF), show that the data from 511 leaves did not fit a normal distribution $(\mathrm{p} \leq 0.05)$ (Table 1).

Table 1. Descriptive statistics and normality test for the length of the central leaflet (C), the width of the central leaflet $(\mathrm{L})$, the product of length and width $(\mathrm{L} \times \mathrm{W})$, the leaf area determined by digital imaging (ID) and the leaf area determined by leaf discs (DF) of 511 leaves of guava 'Paluma'

\begin{tabular}{llllll}
\hline Statistic & $\mathrm{C}$ & $\mathrm{L}$ & $\mathrm{C} \times \mathrm{L}$ & $\mathrm{ID}$ & $\mathrm{DF}$ \\
\hline Minimum & 7.88 & 2.81 & 22.13 & 48.55 & 49.43 \\
Maximum & 15.00 & 6.97 & 104.53 & 333.05 & 337.29 \\
Mean & 11.46 & 5.19 & 60.35 & 168.19 & 169.60 \\
Median & 11.50 & 5.21 & 59.89 & 163.09 & 164.06 \\
Standard deviation & 1.29 & 0.71 & 14.67 & 49.70 & 49.94 \\
\hline $\mathrm{CV}(\%)$ & 11.21 & 13.59 & 24.30 & 29.54 & 29.45 \\
$\mathrm{C}_{\mathrm{s}}$ & -0.55 & -0.22 & +0.18 & +0.44 & +0.46 \\
$\mathrm{C}_{\mathrm{k}}$ & -0.93 & -0.09 & -0.26 & +0.22 & +0.26 \\
$\mathrm{D}$ & $0.657^{*}$ & $0.135^{*}$ & $0.268^{*}$ & $0.0526^{*}$ & $0.0775^{*}$ \\
\hline
\end{tabular}

Note. Cs: Coefficient of asymmetry; Ck: Coefficient of kurtosis; D: significance of the Kolmogorov-Smirnov test; *: Significant ns: not significant.

Though variability in relation to the average data of $\mathrm{L}$ and High $\mathrm{W}$ cannot be considered as their coefficients of variation were 11.21 and $13.59 \%$, respectively, it can be concluded that the sample is suitable for the generation of regression models because the variability of leaf area determined by ID and DF was considerably higher, demonstrating the adequacy of the sample. The average leaf area determined by DF was $0.84 \%$ higher than the leaf area determined by ID, indicating the compatibility of the methods. Toebe et al. (2012) did not verify the normality for the variables length, width and the product of length when they performed a similar experiment to determine the leaf area of the bean vargem by two methods (discs and digital photos), and they found a difference of $16 \%$ mean leaf area between the two methods.

Figure 1 shows the fit of the simple linear regression between leaf area determined by digital imaging and the leaf area determined by leaf discs. 


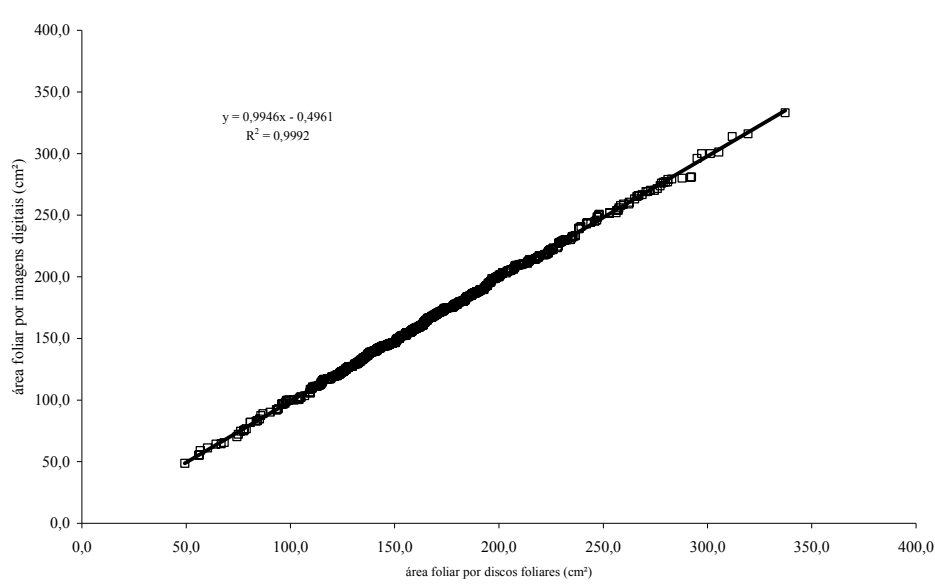

Figure 1. Simple linear regression between the leaf area determined by digital imaging and the leaf area determined by leaf discs of 511 guava leaves

The linear and angular coefficients of the simple linear regression of leaf area determined by digital imaging as a function of leaf area determined by leaf discs were close to zero $(a=-0.4961, p \leq 0,05)$ and close to one $(b=$ $0.9946, \mathrm{p} \leq 0.05)$, respectively. An angular coefficient close to 1 indicates that measurements of leaf area determined by the two methods are mathematically similar. Furthermore, there is a decreasing trend $(\mathrm{a}=$ -0.4961 ); that is, the larger the leaves, the smaller the differences between the leaf area determined by the two methods. However, the percentage change in the mean area of the two methods remained constant. The model $\hat{Y}$ $=-0.4961+0.9946 \mathrm{x}$ indicates that for every one-unit increase in leaf area determined by leaf discs, the leaf area determined by digital images increases, on average, 0.9946 units. Thus, it can be inferred that the methods provide approximately equal leaf areas because the coefficients of linear correlation $(r=0.9996, p \leq 0.05)$ and determination $\left(R^{2}=0.9992\right)$, even though they are high values, need to be analysed from a practical standpoint; essentially, there is a linear relationship between the variables. Bosco et al. (2012) conducted a similar study to select regression models to estimate the leaf area in apple and determined, for all selected, the significances of angular and linear coefficient models. This highlights the importance of this type of analysis, beyond the linear correlation coefficient. Methods for the determination of leaf area using digital photos and leaf discs provide different results, although the correlation coefficients are high; a similar conclusion was obtained by Toebe et al. (2012), working to determine the leaf area of green beans.

The model (quadratic and power) that relates leaf area determined by digital images and by leaf discs with the full leaf measurements of length, width and/or the product of length and width showed similar adjustments (Tables 2 and 3). The high values of the coefficients of determination $\left(R^{2} \geq 0.989\right)$ indicate that all models could be used to estimate leaf area. 
Table 2. Equations for determining the leaf area ratio (Y) of leaf discs and digital images using the length (L) width $(\mathrm{W})$ and the product of length and width $(\mathrm{L} \times \mathrm{W})$ as independent variables $(\mathrm{x})$

\begin{tabular}{lll}
\hline Model & Independent Variable & Estimated Equation \\
\hline Area Leaf Discs & & \\
1. Linear & $\mathrm{C}$ & $\mathrm{Y}=38.415 \mathrm{x}-270.59$ \\
2. Linear & $\mathrm{L}$ & $\mathrm{Y}=69.642 \mathrm{x}-191.71$ \\
3. Linear & $\mathrm{C} \times \mathrm{L}$ & $\mathrm{Y}=3.386 \mathrm{x}-34.751$ \\
4. Quadratic & $\mathrm{C}$ & $\mathrm{Y}=2.824 \mathrm{x}^{2}-26.115 \mathrm{x}+93.358$ \\
5. Quadratic & $\mathrm{L}$ & $\mathrm{Y}=11.497 \mathrm{x}^{2}-47.842 \mathrm{x}+102.640$ \\
6. Quadratic & $\mathrm{C} \times \mathrm{L}$ & $\mathrm{Y}=0.012 \mathrm{x}^{2}+1.890 \mathrm{x}+8.731$ \\
7. Potential & $\mathrm{C}$ & $\mathrm{Y}=0.226 \mathrm{x}^{2.704}$ \\
8. Potential & $\mathrm{L}$ & $\mathrm{Y}=4.531 \mathrm{x}^{2.186}$ \\
9. Potential & $\mathrm{C} \times \mathrm{L}$ & $\mathrm{Y}=1.174 \mathrm{x}^{1.211}$ \\
Area Digital Images & & \\
10. Linear & $\mathrm{C}$ & $\mathrm{Y}=38.237 \mathrm{x}-269.96$ \\
11. Linear & $\mathrm{L}$ & $\mathrm{Y}=69.336 \mathrm{x}-191.53$ \\
12. Linear & $\mathrm{C} \times \mathrm{L}$ & $\mathrm{Y}=3.370 \mathrm{x}-35.206$ \\
13. Quadratic & $\mathrm{C}$ & $\mathrm{Y}=2.759 \mathrm{x}^{2}-24.822 \mathrm{x}+85.693$ \\
14. Quadratic & $\mathrm{L}$ & $\mathrm{Y}=11.331 \mathrm{x}^{2}-46.456 \mathrm{x}+98.587$ \\
15. Quadratic & $\mathrm{C} \times \mathrm{L}$ & $\mathrm{Y}=0.011 \mathrm{x}^{2}+1.938 \mathrm{x}+6.401$ \\
16. Potential & $\mathrm{C}$ & $\mathrm{Y}=0.217 \mathrm{x}^{2.716}$ \\
17. Potential & $\mathrm{L}$ & $\mathrm{Y}=4.414 \mathrm{x}^{2.196}$ \\
18. Potential & $\mathrm{C} \times \mathrm{L}$ & $\mathrm{Y}=1.136 \mathrm{x}^{1.217}$ \\
\hline
\end{tabular}

Eighteen estimated models of leaf area with high coefficients of determination $\left(\mathrm{R}^{2}>0.95\right)$ were obtained (shown in Table 3). Model tests showed significant differences $(p<0.05)$ in the estimation of leaf area as a function of $C$ and/or L. The quadratic and power models gave values of coefficients of determination $\left(\mathrm{R}^{2}\right)$ greater than the linear models.

Table 3. Angular ratio (a), linear (b), linear correlation (r) and determination $\left(\mathrm{R}^{2}\right)$ coefficients obtained for the adjusted leaf area between the estimated and observed linear regressions. Mean absolute error (MAE), root mean square error (RMSE), Willmott index (d) and Camargo and Sentelhas index (CS)

\begin{tabular}{|c|c|c|c|c|c|c|c|c|}
\hline Model & $\mathrm{a}$ & $\mathrm{b}$ & $\mathrm{r}$ & $\mathrm{R}^{2}$ & MAE & RMSE & $\mathrm{d}$ & $\mathrm{CS}$ \\
\hline 1 & 0.977* & $3.850^{*}$ & 0.989* & 0.977 & 6.108 & 7.515 & 0.994 & 0.983 \\
\hline 2 & $0.967 *$ & $5.557^{*}$ & $0.983 *$ & 0.967 & 7.254 & 9.030 & 0.992 & 0.975 \\
\hline 3 & $0.989 *$ & $1.900^{*}$ & $0.994 *$ & 0.989 & 4.418 & 5.290 & 0.997 & 0.992 \\
\hline 4 & $0.992 *$ & $1.391^{*}$ & $0.996^{*}$ & 0.992 & 3.595 & 4.521 & 0.998 & 0.994 \\
\hline 5 & $0.991^{*}$ & $1.443^{*}$ & $0.996^{*}$ & 0.992 & 3.830 & 4.606 & 0.998 & 0.994 \\
\hline 6 & $0.992 *$ & $1.203^{\mathrm{ns}}$ & $0.997 *$ & 0.993 & 3.305 & 4.054 & 0.998 & 0.995 \\
\hline 7 & $1.006^{*}$ & $-1.040^{\mathrm{ns}}$ & $0.996^{*}$ & 0.984 & 3.635 & 4.430 & 0.998 & 0.994 \\
\hline 8 & $0.970 *$ & $5.006^{*}$ & $0.995 *$ & 0.989 & 4.219 & 5.218 & 0.997 & 0.992 \\
\hline 9 & $0.988^{*}$ & $1.966^{*}$ & $0.996^{*}$ & 0.989 & 3.745 & 4.492 & 0.998 & 0.994 \\
\hline 10 & $0.978 *$ & $3.706^{*}$ & $0.989^{*}$ & 0.978 & 5.981 & 7.369 & 0.994 & 0.983 \\
\hline 11 & $0.968 *$ & $5.327^{*}$ & $0.984 *$ & 0.968 & 6.984 & 8.836 & 0.992 & 0.976 \\
\hline 12 & $0.989 *$ & $1.790^{*}$ & $0.995^{*}$ & 0.989 & 4.342 & 5.122 & 0.997 & 0.992 \\
\hline 13 & $0.992 *$ & $1.355^{\text {ns }}$ & $0.996^{*}$ & 0.992 & 3.492 & 4.459 & 0.998 & 0.994 \\
\hline 14 & $0.992 *$ & $1.329 *$ & $0.996^{*}$ & 0.992 & 3.569 & 4.413 & 0.998 & 0.994 \\
\hline 15 & $0.993 *$ & $1.110^{\mathrm{ns}}$ & $0.997 *$ & 0.994 & 3.073 & 3.954 & 0.998 & 0.995 \\
\hline 16 & $1.008^{*}$ & $-1.273^{\mathrm{ns}}$ & $0.996^{*}$ & 0.985 & 3.535 & 4.389 & 0.998 & 0.994 \\
\hline 17 & $0.971^{*}$ & $4.686^{*}$ & $0.995^{*}$ & 0.989 & 3.986 & 4.979 & 0.997 & 0.993 \\
\hline 18 & $0.990 *$ & $1.688^{*}$ & $0.996^{*}$ & 0.989 & 3.593 & 4.327 & 0.998 & 0.994 \\
\hline
\end{tabular}


The quadratic and power models adjusted for the product of width and length had a higher performance (higher values of $\mathrm{R}^{2}$ ) when length and width were analysed separately. Models for crop snap beans, passion fruit (Toebe et al., 2012; Morgado et al., 2013), melon (Lopes et al., 2007), crambe (Toebe et al., 2010) and tropical forage (Sousa et al., 2015) yielded different results, with lower coefficients of determination when the variable length was determined by digital photos or leaf discs. However, it is noteworthy that the differences between the coefficients of variation of the models found in this study were very small, less than $0.1 \%$ percent different. Therefore, due to the high labour required to collect two variables (length and width), there is no justification for the use of these equations, so we suggest the use of equations that consider only the variable width or length for both practicality and accuracy of results.

It can be inferred that the quadratic power models based on the length or width are more appropriate than other models. Queiroga et al. (2003), Maldaner et al. (2009), Toebe et al. (2010), and Silva et al. (2015) concluded that quadratic power models using the width of the leaf presented better results for the determination of leaf area; this agrees with our results for guava leaves. It is advantageous to use only one dimension of the leaf for determining leaf area, regardless of the size.

\section{Conclusion}

Guava leaf area can be determined by simple measures of its linear dimensions.

The $m$ of all leaf discs and scanned images is in agreement for the estimation of the leaf area; given that the dimension is used, the first is the appropriate length and width.

Although it disagrees with the use of linear dimensions of the leaf, $m$ offers good accuracy in determining the leaf area, and the wood frame model was the best fit for the two methods.

\section{References}

Araújo, E. C. E., Santos, E. P., \& Prado, C. H. B. A. (2005). Leaf area estimation of mango (Mangifera indica L.) cvs tommy atkins and haden, using linear dimensions. Revista Brasileira de Fruticultura, 27(2), 308-30. https://doi.org/10.1590/S0100-29452005000200030

Borghezan, M., Gavioli, O., Pit, F. A., \& Silva, A. L. (2010). Mathematical models for the estimation of leaf area of grape varieties to the field (Vitis vinifera L.). Ciência e Técnica Vitivinícola, 25(1), 1-7.

Bosco, L. C., Bergamaschi, H., Cardoso, L. S., \& Paula, V. A. (2012). Selection of regression models for estimating leaf area of 'royal gala' and 'fuji suprema' apple trees under hail net and in open sky. Revista Brasileira de Fruticultura, 34(2), 504-514. https://doi.org/10.1590/S0100-29452012000200024

Camargo, A. P., \& Sentelhas, P. C. (1997). Evaluation of the performance of different methods of estimation of potential evapotranspiration in the State of São Paulo. Revista Brasileira de Agrometeorologia, 5(1), 89-97.

Lima, R. T. D., Souza, P. J. O. P., Rodrigues, J. C., \& Lima, M. J. A. (2012). Models for estimating leaf area of mango, using linear measures. Revista Brasileira de Fruticultura, 34(4), 974-980. https://doi.org/10.1590/ S0100-29452012000400003

Lopes, S. J., Brum, B., Santos, V. J., Fagan, E. B., \& Luz, G. M (2007). Estimativa da área foliar de meloeiro em estádios fenológicos por fotos digitais. Ciência Rural, 37(4), 1153-1156. https://doi.org/10.1590/S010384782007000400039

Lucena, R. R., Batista, T. M. V., Dombroski, J. L. D., Lopes, W. A. R., \& Rodrigues, G. S. O. (2011). Measurement of acerola leaf area. Revista Caatinga, 24(2), 1-5.

Maldaner, I. C., Heldwein, A. B., Loose, L. H., Lucas, D. D. P., Guse, F. I., \& Bortoluzzi, M. P. (2009). Models for estimating leaf area in sunflower. Ciência Rural, 39(5), 1356-1361. https://doi.org/10.1590/S0103-847 82009000500008

Morgado, M. A. D. O., Bruckner, C. H., Rosado, L. D. S, Assunção, W., \& Santos, C. E. M. (2015). Estimação da área foliar por método não destrutivo, utilizando medidas lineares das folhas de espécies de Passiflora1. Revista Ceres, 60(5), 662-667. https://doi.org/10.1590/S0034-737X2013000500009

Pereira, F. M., \& Kavati, R (2011). Contribution of the Brazilian scientific research in the development of some fruit trees of subtropical climate. Revista Brasileira de Fruticultura, 33(1), 92-108. https://doi.org/10.1590/ S0100-29452011000500013

Queiroga, J. L. (2003). Model to estimate the leaf area of snap bean. Horticultura Brasileira, 21(1), 64-68. https://doi.org/10.1590/S0102-05362003000100013 
R Core Team. (2013). R: A language and environment for statistical computing. R Foundation for Statistical Computing, Vienna, Austria.

Ramos, D. P., Silva, A. C., Leonel, S.; Costa, S. M., \& Damatto Júnior, E. R. (2010). Produção e qualidade de frutos da goiabeira 'Paluma', submetida à diferentes épocas de poda em clima subtropical. Revista Ceres, 57(5), 659-664. https://doi.org/10.1590/S0034-737X2010000500015

Rasband, W. S. (2012). ImageJ: Image processing and analysis in Java. Astrofisica Source Code Library, 1, 613.

Silva, L. C., Santos, J. W., Vieira, D. J., Beltrão, N. E. M., Alves, I., \& Jerônimo, J. F. (2002). A simple method to estimate leaf area of sesame plants (Sesamum indicum L.). Revista Brasileira de Oleaginosas e Fibrosas, 6(1), 491-496.

Silva, S. F., Cabanez, P. A., Mendonça, R. F., Peeira L. R., \& Amaral, J. A. T (2015). Allometric models for estimating leaf area of hose by non destructive method. Revista Agroambiente, 9(1), 86-90.

Sousa, L. F., Santos, J. G. D., Alexandrino, E., Mauricio, R. M., Martins, A. D., \& Sousa, J. T. L. (2015). Método prático e eficiente para estimar a área foliar de gramíneas forrageiras tropicais. Archivos Zootecnia, 64(1), 83-85.

Toebe, M., Brum, B., Lopes, S. J, Filho, A. C., \& Silveira, T. R. (2010). Estimate leaf area of Crambe abyssinica for leaf discs and digital photos. Ciência Rural, 40(2), 445-448. https://doi.org/10.1590/S0103-847820 10000200036

Toebe, M. et al. (2012). Leaf area prediction models for jack bean by leaf dimensions. Bragantia, 71(1), 37-41. https://doi.org/10.1590/S0006-87052012005000010

Wilmott, C. J., Ackleson, S. G., Davis, R. E., Feddema, J. J., Klink, K. M., Legates, D. R., ... Rowe, C. M. (1995). Statistics for the evaluation and comparison of models. Journal of Geophysical Research, 90(5), 8995-9005. https://doi.org/10.1029/JC090iC05p08995

\section{Copyrights}

Copyright for this article is retained by the author(s), with first publication rights granted to the journal.

This is an open-access article distributed under the terms and conditions of the Creative Commons Attribution license (http://creativecommons.org/licenses/by/4.0/). 